\title{
Yin and Yang - the Gastric X/A-like Cell as Possible Dual Regulator of Food Intake
}

\author{
Andreas Stengel ${ }^{1 *}$ and Yvette Taché ${ }^{2}$ \\ ${ }^{1}$ Department of Medicine, Division Psychosomatic Medicine and Psychotherapy, Charité, Campus Mitte, Universitätsmedizin Berlin, Berlin, \\ Germany; and ${ }^{2}$ CURE/Digestive Diseases Research Center, Center for Neurobiology of Stress, Department of Medicine, Digestive Diseases \\ Division at the University of California Los Angeles; and VA Greater LoS Angeles Health Care System, Los Angeles, CA, USA
}

\begin{abstract}
Ingestion of food affects secretion of hormones from enteroendocrine cells located in the gastrointestinal mucosa. These hormones are involved in the regulation of various gastrointestinal functions including the control of food intake. One cell in the stomach, the X/A-like has received much attention over the past years due to the production of ghrelin. Until now, ghrelin is the only known orexigenic hormone that is peripherally produced and centrally acting to stimulate food intake. Subsequently, additional peptide products of this cell have been described including desacyl ghrelin, obestatin and nesfatin-1. Desacyl ghrelin seems to be involved in the regulation of food intake as well and could play a counter-balancing role of ghrelin's orexigenic effect. In contrast, the initially proposed anorexigenic action of obestatin did not hold true and therefore the involvement of this peptide in the regulation of feeding is questionable. Lastly, the identification of nesfatin- 1 in the same cell in different vesicles than ghrelin extended the function of this cell type to the inhibition of feeding. Therefore, this X/A-like cell could play a unique role by encompassing yin and yang properties to mediate not only hunger but also satiety.
\end{abstract}

(J Neurogastroenterol Motil 2012;18:138-149)

Key Words

Desacyl ghrelin; Eating; Ghrelin; Nucleobindin; Obesity; Obestatin; Stomach

\section{Introduction}

The stomach is the first site where food has a sustained contact with the gastrointestinal tissue. Therefore, it is not surprising that the stomach plays an important role in the regulation of hunger and satiety. In the past years specialized endocrine cells drew increasing attention and stimulated research in the field of physiology, behavioral medicine and obesity research. Different endocrine cells present in the stomach were shown to regulate physio- logical functions, predominantly gastric acid secretion. These cells encompass gastrin-producing cells, in low quantity serotonin-producing enterochromaffin cells, somatostatin-producing D cells $(5 \%-10 \%$ of gastric oxyntic endocrine cells in rats, $>20 \%$ in humans) and histamine-containing enterochromaffin-like cells (65\% in rats and $30 \%$ in humans). ${ }^{1}$ Another cell type has been described that resembled the phenotype of pancreatic A cells although the function was unknown. ${ }^{1}$ Therefore, this cell was termed X/A-like cell (in humans the same cell was named $\mathrm{P} / \mathrm{D}_{1}$ cell). ${ }^{2,3}$ This cell type accounts for $20 \%-30 \%$ of the endocrine cell

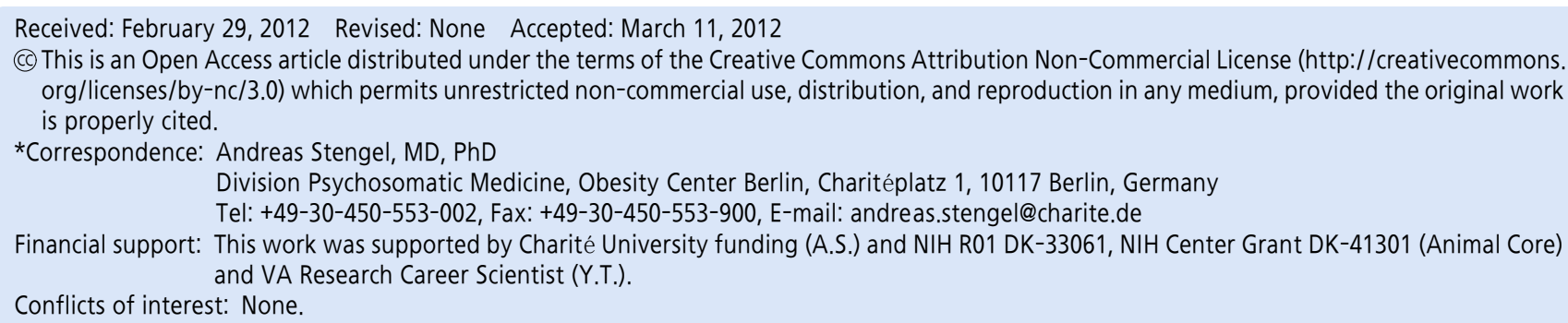


population in the gastric oxyntic mucosa and is distributed throughout the mucosal layer. ${ }^{4}$ In addition to the stomach, $\mathrm{X} / \mathrm{A}$-like cells were also found in lower parts of the gastrointestinal tract with decreasing quantities. ${ }^{4}$ Interestingly, whereas in the stomach the predominant type of X/A-like cells is of round shape without contact to the lumen (closed-type), with aboral distance from the stomach, the percentage of elongated cells with luminal contact (open-type) increases. ${ }^{4}$ In 1999 the food intake stimulatory peptide hormone ghrelin was discovered, ${ }^{5}$ and the identification of ghrelin in X/A-like cells ${ }^{2,6}$ stimulated research on this particular cell and its peptide product(s). In the following years, additional peptide products of X/A-like cells have been identified, namely desacyl ghrelin, obestatin and nesfatin-1 which were also suggested to be involved in feeding regulation. This review will discuss the current knowledge on these peptides products and recent concepts on the involvement of this particular cell type in the regulation of not only hunger but also satiety.

\section{Products of the X/A-like Cell}

Besides ghrelin, desacyl ghrelin and $n$-decanoyl ghrelin ${ }^{2,7}$ as well as obestatin ${ }^{8}$ are derived from the same gene whereas nucleobindin2 (NUCB2)/nesfatin- ${ }^{9}$ is encoded by a different gene.

\section{Ghrelin, Desacyl Ghrelin and n-Decanoyl Ghrelin}

In 1999 Kangawa and Kojima discovered the growth hormone secretagogue, ghrelin as the endogenous ligand of the growth hormone secretagogue receptor $1 \mathrm{a}^{5,10}$ which was later renamed ghrelin receptor (GRLN-R). ${ }^{11}$ The 28 amino acid peptide has a unique fatty acid modification on the third amino acid. This n-octanoic residue is essential for the binding to the GRLN-R ${ }^{5,12}$ by increasing the peptide's lipophilicity. ${ }^{5}$ A recent study showed that medium chain fatty acids in the diet are the direct source for ghrelin's hydrophobic modification. ${ }^{13}$ Interestingly, also the first $5 \mathrm{~N}$-terminal amino acids can activate the receptor when they bear a fatty acid residue. ${ }^{14}$ Recently, n-decanoyl ghrelin was identified as another acylated form and shown to represent a major circulating form of ghrelin in mice. ${ }^{7}$

The enzyme catalyzing the acylation of ghrelin was identified very recently in mice and humans as a member of the membrane-bound $O$-acyltransferases (MBOATs), MBOAT4 that was renamed ghrelin-O-acyltransferase (GOAT). ${ }^{15,16}$ Both, $\mathrm{C} 8$ and $\mathrm{C} 10$ medium chain fatty acids are substrates for GOAT resulting in octanoyl and decanoyl ghrelin. ${ }^{16}$ It is assumed that GOAT acetylates pro-ghrelin before its transport to the Golgi apparatus where pro-ghrelin is cleaved by prohormone convertase $1 / 3 .^{15}$ Interestingly, in addition to GOAT mRNA and protein expression in gastric X/A-like cells, ${ }^{17,18}$ GOAT immunoreactivity was also identified in the circulation of rats and mice $^{18}$ raising the possibility of an extracellular acyl modification of ghrelin.

In contrast to ghrelin, desacyl ghrelin does not bear a fatty acid residue and therefore does not bind to the GRLN-R. ${ }^{5}$ Both ghrelin and desacyl ghrelin are predominantly derived from gastric X/A-like cells and represent the major circulating forms with a proportion in the blood initially reported to range between $1: 15^{19}$ and $1: 55{ }^{20}$ However, recent advances in blood processing for labile peptides indicated a proportion of acyl/total ghrelin of 1:5 compared to $1: 19$ observed after standard blood processing (EDTA blood on ice). ${ }^{21}$

\section{Obestatin}

In 2005, a computer-based search for alternative splicing and post-translational processing predicted the cleavage site of proghrelin leading to obestatin, a peptide assumed to curtail body weight and to antagonize ghrelin's orexigenic action. ${ }^{8,22}$ Obestatin is also expressed in human gastric endocrine $\mathrm{P} / \mathrm{D} 1$ cells $^{23,24}$ and rat gastric $\mathrm{X} / \mathrm{A}$-like cells ${ }^{25}$ with a subcellular localization in secretory granules. $^{23,24}$

\section{Nucleobindin2/Nesfatin-1}

The group of Mori recently reported the identification of NUCB2/nesfatin-1 in the rat hypothalamus. ${ }^{26}$ Subsequent studies confirmed this finding ${ }^{27-29}$ and extended its expression to the periphery with a 10 -fold higher $\mathrm{mRNA}$ expression in gastric mucosa than in the brain. ${ }^{9}$ Interestingly, ghrelin and nesfatin-1 immunoreactivity co-localized in the same oxyntic endocrine X/Alike cells as visualized by double immunofluorescence staining and high-resolution confocal microscopy from a single X/A-like cell indicated the occurrence of these 2 peptides in different subsets of vesicles. ${ }^{9}$ Another finding indirectly supporting the production of ghrelin and nesfatin- 1 in the same cell came from the observation of prohormone convertase $1 / 3$ in X/A-like cells, ${ }^{15}$ a hormone involved in the processing of both peptides. ${ }^{15,30}$

\section{Peptide Release and Action on Receptors -}

\section{Ghrelin and Desacyl Ghrelin}

Ghrelin is mainly produced by gastric X/A-like cells ${ }^{31}$ as in- 
dicated by a pronounced decrease of circulating ghrelin levels after gastrectomy. ${ }^{32}$ In addition, ghrelin is produced in the intestine, ${ }^{2}$ pancreas ${ }^{33}$ and other peripheral organs, namely kidney, liver, heart, testis, adipose tissue and skin, ${ }^{34,35}$ although in much lower quantities compared to the gastric source. Circulating ghrelin levels are largely affected by the metabolic condition with an increase before meals and a decrease thereafter. ${ }^{36,37}$ Moreover, fasting stimulates ghrelin mRNA expression, ${ }^{38-40}$ whereas gastric ghrelin peptide content decreases pointing towards stimulated production and release of ghrelin under these conditions. ${ }^{39,40}$ In addition to these short-term changes, circulating ghrelin concentrations depend on the metabolic status over time with increased levels under conditions of anorexia and cachexia and a decrease in overweight and obese subjects. ${ }^{41-43}$ Similar to the observed changes of ghrelin, gastric GOAT mRNA as well as circulating GOAT protein levels were increased during fasting conditions. $^{18,44}$

Ghrelin is affected by a multitude of hormones and transmitters which were tested in vitro and in vivo. The most established action is the inhibitory effect of somatostatin on circulating levels of ghrelin reported in experimental studies and humans, ${ }^{45-47}$ likely mediated via the somatostatin receptor subtype 2 which is expressed on X/A-like cells (P/D1 cells) in animals ${ }^{48}$ and humans. ${ }^{49}$ Similarly, prostacyclin is likely to reduce circulating ghrelin levels ${ }^{50}$ via direct interaction with the prostacyclin $\mathrm{I}_{2}$ receptor expressed on X/A-like cells. ${ }^{50}$ Moreover, glucagon-like peptide, ${ }^{51-53}$ cholecystokinin- $8,{ }^{54}$ insulin $^{46,55}$ and bombesin ${ }^{45}$ reduce circulating levels of ghrelin although the mode of interaction remains to be established. On the other hand, central vagal cholinergic activation ${ }^{56,57}$ and adrenaline as well as noradrenaline, ${ }^{45,46,58}$ have been consistently shown to increase circulating levels of ghrelin in experimental animals. Stimulatory effects of dopamine have been reported in vitro ${ }^{46}$ but not in vivo. ${ }^{45}$ The ghrelin releasing effect of cannabinoids, ${ }^{59}$ oxytocin and vasopressin, ${ }^{46}$ secretin, ${ }^{45}$ and endothelin 1 and $3{ }^{45,61}$ were reported either in vitro or in vivo and are yet to be further confirmed. However, one has to note that the underlying mechanisms regulating ghrelin production and release at the cellular and molecular levels are poorly characterized. Establishing pure preparations of isolated ghrelin cells using ghrelin promoter models coupled to fluorescent dye ${ }^{62}$ or the recent use of the ghrelin-producing mouse cell line, MGN3-16 ${ }^{46}$ could be promising venues to conduct these investigations.

Interestingly, acyl and desacyl ghrelin are not uniformly regulated as shown by a recent study where lowering the gastric
$\mathrm{pH}$ stimulated the release of desacyl ghrelin whereas acyl ghrelin was not affected. ${ }^{3}$ In addition, also immunological ${ }^{63}$ or physical $^{48}$ stressors lead to differential ratios of circulating levels of acyl and desacyl ghrelin indicative of a more rapid decrease of the acylated form, which could be attributed to a reduction in GOAT protein expression as recently suggested. ${ }^{48}$ However, the exact mechanisms are unknown and warrant future investigation.

Ghrelin is the endogenous ligand of the GRLN-R which is expressed in the brain and peripheral structures and organs including the pituitary, vagal afferents, pancreas, spleen, myocardium, adipose tissue, thyroid gland, adrenal gland and gastric myenteric neurons. ${ }^{34,64-66}$ This receptor is characterized by high constitutive activity ${ }^{67}$ which is likely to hamper blockade of ghrelin signaling by ghrelin antagonists and may favor the development of inverse agonists. ${ }^{68}$ In addition, the GRLN-R forms heterodimers with other receptors such as the cannabinoid 1 receptor $^{65}$ and the dopamine receptor $1^{69}$ thought to result in increased signaling. Conversely, the GRLN-R desensitizes after stimulation through endocytosis via clathrin-coated pits and is characterized by slow dissociation with ghrelin, ${ }^{70}$ likely preventing available GRLN-R available for binding.

Unlike ghrelin, desacyl ghrelin is unable to bind to the GRLN-R and the receptor for this peptide remains to be established. The existence of a specific desacyl ghrelin receptor is strongly suspected based on the findings that desacyl ghrelin exerts several biological actions in cells that do not express the GRLN-R, as shown by the inhibition of cell proliferation in breast cancer ${ }^{71}$ and prostate cancer ${ }^{72}$ cell lines and stimulation of insulin release from INS-1E cells. ${ }^{73}$

\section{Obestatin}

In contrast to the suggested role of obestatin as regulator of food intake, obestatin levels do not change dependent on metabolic status. ${ }^{8,74}$ During fasting conditions gastric obestatin peptide content ${ }^{25}$ and plasma obestatin levels ${ }^{8}$ remain unaltered. One study reported a decrease of circulating obestatin during fasting, ${ }^{75}$ a finding to be replicated. Initially, obestatin was described as the endogenous ligand of the 7 transmembrane domain $G$ protein-coupled receptor, GPR $39 .^{8}$ However, subsequent studies conducted by several independent groups ${ }^{76-79}$ as well as the original investigators ${ }^{80}$ did not reproduce the initial findings of binding of obestatin to recombinant GPR39 and activation of the receptor. However, recent studies by Zhang et $\mathrm{al}^{81}$ provided new evidence for obestatin binding to GPR39 to regulate functions of diverse gastrointestinal and adipose tissues. One has to note that 
the GPR39 displays high constitutive activity in the absence of ligand binding similar to the GRLN-R. ${ }^{82}$ Taken together, there is need for further experiments in order to elucidate the endogenous ligand of the GPR39.

\section{Nucleobindin2/Nesfatin-1}

Plasma NUCB2/nesfatin-1 is regulated by nutritional status with a significant decrease after 24-hour fasting in rats and a return to baseline after refeeding. ${ }^{9}$ However, so far these meal-related alterations have not been observed in humans under conditions where ghrelin levels are decreased. ${ }^{83,84}$ Interestingly, a study in non-obese male subjects showed a negative correlation between body mass index (BMI) and fasting plasma levels of NUCB2/nesfatin-1. ${ }^{83}$ In addition, other groups reported a positive correlation between NUCB2/nesfatin-1 plasma levels and BMI with lower levels in anorexic patients ${ }^{85}$ and higher levels in obese subjects ${ }^{86,87}$ giving rise to the regulation of NUCB2/nesfatin-1 by the amount of white adipose tissue, a tissue where NUCB2/nesfatin-1 was recently identified to be expressed. ${ }^{86}$

It is important to note that mature nesfatin-1 $(10 \mathrm{kDa})$ has been described only in the initial report so far. ${ }^{26}$ Subsequent studies only detected full length NUCB2 $(47 \mathrm{kDa})$ in the brain, ${ }^{28,88,89}$ gastric mucosa, pancreas, pituitary and adipose tissue, ${ }^{9,86}$ whereas exogenous nesfatin-1 could be visualized with the techniques used. ${ }^{9,89}$ This discrepancy raises the possibility of post-secretory processing of NUCB2 to nesfatin-1 in the blood or cerebrospinal fluid. This hypothesis is supported by the finding of processed nesfatin-1 in human plasma samples using a sensitive sandwich-type ELISA recognizing exclusively nesfatin-1 but not full length NUCB2. ${ }^{83}$

Despite the fact that our knowledge on the regulation of NUCB2/nesfatin-1 has increased over the past years, the receptor mediating NUCB2/nesfatin-1's actions remains to be identified. One study suggested an interaction with a G-protein-coupled receptor based on the finding that nesfatin-1 led to an increase of $\left[\mathrm{Ca}^{2+}\right]$ linked with protein kinase A signaling in isolated cultured rat hypothalamic cells. ${ }^{27}$

\section{Effects on Food Intake and Energy Homeo- stasis}

Although the physiological role of obestatin remains controversial $^{90}$ and those of desacyl ghrelin ${ }^{91}$ and nesfatin- $1^{92}$ are still scarcely described, all these products of the X/A-like cell have been implicated in feeding regulation with ghrelin being the only stimulator of food intake and desacyl ghrelin and nesfatin-1 exerting anorexigenic actions.

\section{Ghrelin, Desacyl Ghrelin and n-Decanoyl Ghrelin}

Contrasting with the multitude of anorexigenic modulators of feeding, ${ }^{93}$ ghrelin is the only known peripherally produced and centrally acting hormone that stimulates food intake in animals ${ }^{94,95}$ and humans. ${ }^{96}$ In line with the similar binding of octanoyl as well as $n$-decanoyl ghrelin to the GRLN-R, both forms stimulate feeding ${ }^{7}$ and ghrelin-induced feeding is inhibited by various GRLN-R antagonists. ${ }^{97}$ Further corroborating the key role of this receptor, injection of ghrelin did not result in an orexigenic response in GRLN-R knockout mice. ${ }^{98,99}$ Ghrelin stimulates food intake via direct actions on the GRLN-R located on food regulatory brain nuclei after passage through the bloodbrain barrier ${ }^{100,101}$ and expressed on vagal afferents well established to convey gut peptide signaling influencing food intake. ${ }^{102,103}$ Further supporting the importance of vagal signaling, subdiaphragmatic or gastric vagotomy prevented the orexigenic response to intravenous injection of ghrelin in rats. ${ }^{102}$ However, another study reported a stimulation of food intake by intraperitoneally injected ghrelin in rats that underwent elective subdiaphragmatic vagal deafferentation. ${ }^{104}$ These discrepant results may be related to different routes of administration of the peptide, higher doses recruiting alternative mechanisms and modalities of surgery that should be delineated in future studies.

As suggested by the negative correlation with BMI, ghrelin is not only affected by chronic changes in metabolic status but also involved in the long-term regulation of body weight homeostasis. Chronic infusion of ghrelin increases body weight gain in rodents which is due to increased appetite but also caused by the stimulation of fat storage and decrease of lipid mobilization resulting in enlargement of the fat depots. ${ }^{41,105,106}$ In line with these findings, mice lacking both ghrelin and the GRLN-R have an increased energy expenditure associated with a decreased body weight, ${ }^{107}$ whereas mice lacking either ghrelin ${ }^{107,108}$ or the GRLN-R ${ }^{107}$ do not show these alterations leading to the hypothesis of additional ligands and role of constitutive activity of receptors. In addition, ghrelin increased the mRNA expression of fatty acid synthase, acetyl-CoA carboxylase alpha, stearoyl-CoA desaturase- 1 and lipoprotein lipase, all enzymes involved in the mediation of fat storage, whereas the mRNA expression of a major fat oxidation enzyme, carnitine palmitoyl transferase-1alpha, was decreased. ${ }^{109}$ Further supporting the physiological role of ghrelin in these processes, ghrelin knockout mice display 
an opposite expression pattern of these enzymes. ${ }^{109}$ Interestingly, in mice lacking $\beta 1$-, $\beta 2$ - and $\beta 3$-adrenoceptors and injected intracerebroventricularly with ghrelin these changes are not observed $^{109}$ pointing towards an involvement of the sympathetic nervous system in these homeostatic actions of ghrelin. Furthermore, the role of GOAT was investigated using genetic approaches in mice lacking GOAT or over-expressing ghrelin and GOAT. ${ }^{110}$ GOAT knockout mice did not display alterations in body weight when fed a standard rodent diet but showed a reduction of body weight under conditions of high fat diet feeding compared to GOAT expressing wild type littermates. ${ }^{110}$ Interestingly, substituting dietary medium-chain triglycerides results in a decrease of fat mass and body weight in mice lacking GOAT, leading to the speculation of GOAT acting as a lipid sensor. ${ }^{110}$

Besides its peripheral production, ghrelin is also expressed, although in lower quantities, centrally in the arcuate nucleus of the hypothalamus ${ }^{111}$ and in neurons adjacent to the third ventricle. ${ }^{112}$ The arcuate nucleus is crucially involved in the central orchestration of food intake ${ }^{113}$ and neuroanatomical evidence indicated that ghrelin neurons in the arcuate nucleus are connected with neurons containing the orexigenic peptides, ${ }^{114}$ agouti-related peptide (AgRP) and neuropeptide Y (NPY). ${ }^{112,115}$ Peripheral injection of ghrelin selectively activates NPY neurons in mice $^{116}$ and similarly, intracerebroventricular injection of ghrelin activates NPY/AgRP positive arcuate neurons and upregulates the expression of NPY and AgRP mRNA. ${ }^{117}$ The importance of NPY and AgRP signaling for the mediation of ghrelin's orexigenic effects was highlighted pharmacologically using anti-NPY and anti-AgRP antibodies. ${ }^{118}$ Experiments in genetically modified mice showed that animals lacking NPY and AgRP do not respond to a peripheral ghrelin injection, whereas mice lacking either NPY or AgRP still increase food intake upon ghrelin administration ${ }^{119}$ indicating a compensatory action of these two peptides. In addition to the stimulation of these NPY/ AgRP-related orexigenic pathways, ghrelin inhibits the activity of proopiomelanocortin containing neurons resulting in reduced anorexigenic melanocyte stimulating hormone and cocaine- and amphetamine-regulated transcript signaling. ${ }^{112}$

Along with the underlying neural network involved in ghrelin orexigenic action, recent studies underpinned the subcellular signaling mechanisms in theses neurons. Ghrelin increases mitochondrial respiration in NPY arcuate neurons, an effect shown to depend on uncoupling protein 2 (UCP2) by the use of UCP2 knockout mice. ${ }^{120}$ In addition, ghrelin-induced activation of NPY neurons and associated increase of food intake was also re- duced in mice lacking $\mathrm{UCP} 2{ }^{120}$ indicating a crucial involvement of this signaling pathway in ghrelin's orexigenic action. Fasting stimulates phosphorylation of hypothalamic AMP activated protein kinase (AMPK) resulting in decreased hypothalamic levels of malonyl-CoA and increased carnitine palmitoyltransferase 1 activity, effects mimicked by brain injection of ghrelin. ${ }^{121}$ Conversely, blockade of AMPK signaling blunted the feeding stimulatory action of ghrelin. ${ }^{121}$ This ghrelin-induced activation of AMPK was still observed in mice lacking UCP2, ${ }^{120}$ whereas blockade of AMPK signaling reduced food intake in wild type but not UCP2 knockout mice, indicating that UCP2 is a downstream mediator of AMPK. ${ }^{120}$ Lastly, chronic injection of ghrelin results in greater body weight gain in UCP2 knockout mice compared to UCP2 expressing wild type littermates which was associated with decreased fat oxidation, ${ }^{122}$ a finding indicating the importance of UCP2 for the restriction of fat storage.

In contrast to the vast amount of data on ghrelin, the effects of desacyl ghrelin on food intake are less well characterized. ${ }^{123}$ Initial studies reported a capsaicin insensitive reduction of food intake following intraperitoneal injection of desacyl ghrelin in rats ${ }^{124}$ and intracerebroventricular or intraperitoneal injection in mice. ${ }^{125}$ However, other studies did not report this anorexigenic effect following peripheral injection of desacyl ghrelin in fasted rats ${ }^{126}$ or mice. ${ }^{127}$ One study even reported a stimulation of food intake following intracerebroventricular injection of desacyl ghrelin at low dose in rats, ${ }^{128}$ an effect that could reflect acylation of the peptide. In addition, another study showed that intraperitoneal injection of desacyl ghrelin, although not altering food intake when injected alone, abolished the ghrelin-induced stimulation of food intake following simultaneous intraperitoneal injection in rats. ${ }^{126}$ This leads to the hypothesis of an interaction between these two peptide forms which could play a role in the regulation of food intake. Additionally, mice over-expressing both ghrelin and desacyl ghrelin show a decrease of food intake. ${ }^{129}$

In addition to the regulation of food intake, desacyl ghrelin has also been implicated in the regulation of long-term body homeostasis. Mice over-expressing desacyl ghrelin show reduced body size accompanied by a decreased body weight ${ }^{130}$ associated with reduced perirenal and epididymal fat depots ${ }^{131}$ compared to wild type littermates, whereas food intake was not altered ${ }^{130}$ suggesting that desacyl ghrelin may act as a negative regulator of fat storage. However, one has to keep in mind that these mice displayed supraphysiological (10-50 fold increased) circulating desacyl ghrelin levels ${ }^{130}$ that could greatly influence the results. However, in vitro desacyl ghrelin stimulates intracellular lipid ac- 
cumulation in human adipocytes derived from obese subjects ${ }^{132}$ which may contribute to the fat storage under conditions of obesity. These divergent results could be due to in vivo versus in vitro conditions or reflect species differences to be further characterized.

\section{Obestatin}

The initial study describing obestatin suggested a physiological anorexigenic role for obestatin and proposed a counter-regulatory mechanism opposing ghrelin's action. ${ }^{8}$ However, only very few subsequent studies were able to partially reproduce these data, ${ }^{133-136}$ whereas the vast majority of those studies conducted were unable to demonstrate an inhibitory effect of obestatin on food intake or body weight. ${ }^{75,77,78,136-148}$ Thus, obestatin is not considered a physiological regulator of feeding or body weight homeostasis and therefore it was proposed to be renamed ghrelin-associated peptide. ${ }^{149}$

\section{Nucleobindin2/Nesfatin-1}

The landmark paper of Oh-I and colleagues ${ }^{26}$ described a food intake inhibitory action following third ventricular injection of full length NUCB2 and nesfatin-1. In addition, repeated administration reduces body weight gain associated with a decrease in fat mass. The nesfatin-1 injection into the lateral or third brain ventricle-induced anorexigenic action with a delayed onset has been consistently reproduced in consecutive studies in rodents ${ }^{150-155}$ and also in goldfish. ${ }^{88}$ Conversely, blocking endogenous NUCB2/nesfatin-1 signaling using an anti-NUCB2 antisense oligonucleotide or anti-nesfatin-1 antibody injected into the third brain ventricle increased food intake in rats ${ }^{26}$ indicating a physiological inhibitory effect of NUCB2/nesfatin-1 on food intake. In addition to the forebrain action, nesfatin- 1 injected into the hindbrain at the level of the cisterna magna or the fourth ventricle also decreased dark phase food intake within the first hour post injection ${ }^{153}$ pointing towards several responsive brain sites which may involve different downstream signaling. This is also supported by the fact that blockade of the anorexigenic corticotropin releasing factor receptor $2\left(\mathrm{CRF}_{2}\right)$ signaling system ${ }^{156,157}$ using the $\mathrm{CRF}_{2}$ antagonist, astressin 2 - $\mathrm{B}$ injected into the lateral brain ventricle abolished the nesfatin-1-induced decrease of dark phase feeding, while the hindbrain nesfatin-1-induced anorexigenic effect was not altered. ${ }^{153}$ Moreover, the melanocortin 3/4 receptor antagonist, SHU9119 $9^{26,158}$ and an oxytocin antagonist ${ }^{150,154}$ abolished the forebrain nesfatin-1-induced decrease of food intake while leptin signaling is not involved. ${ }^{26,150,159}$ Taken together, nesfatin-1 mediates its anorexigenic action via downstream $\mathrm{CRF}_{2}$, melanocortin 3/4 and oxytocin signaling. In addition, also the blockade of NPY signaling may contribute to the anorexigenic effect based on in vitro data showing that nesfatin-1 hyperpolarizes isolated arcuate NPY neurons. ${ }^{160}$ Interestingly, nesfatin-1 selectively inhibits dark phase food intake under ad libitum feeding conditions, ${ }^{26,150,153,158}$ whereas during the light phase and after fasting inconsistent results were reported. ${ }^{153,158}$ These data may support a specific interaction of nesfatin-1 with other neuronal circuitries uniquely recruited during the physiological dark phase of eating ${ }^{161-163}$ which has to be investigated in future studies. A recent study characterized the feeding microstructure following intracerebroventricular injection of nesfatin-1 in mice showing that the peptide decreases dark phase feeding by inducing satiation (indicated by reduction of meal size) and satiety (indicated by decreased meal frequency associated with prolonged inter-meal intervals). ${ }^{152}$

While good progress has been made in identifying the central food intake reducing actions of nesfatin-1, the peripheral role is less well established. One study reported that full length nesfatin- 1 and the 30 amino acid mid segment, nesfatin- $1_{24-53}$ reduce the dark phase feeding following intraperitoneal injection of a higher dose in ad libitum fed mice. ${ }^{164}$ This is likely mediated by the vagus nerve since capsaicin pretreatment abolishes this effect ${ }^{164}$ and nesfatin- 1 activates the $\mathrm{Ca}^{2+}$ influx in primary cultured nodose ganglion neurons in vitro. ${ }^{165}$ However, another study did not observe the anorexigenic effect of peripherally injected nesfatin-1 in mice and ${ }^{152}$ as well as in rats, ${ }^{153}$ whereas in goldfish only at a high dose, nesfatin-1 also reduces food intake. ${ }^{88}$ Based on these data, nesfatin-1 exerts its anorexigenic action more potently when injected into the brain than peripherally and its peripheral effects still await thorough characterization. Whether different receptor subtypes are involved will also have to be established.

\section{Summary and Perspectives}

During the past decade the gastric endocrine-brain axis was the object of growing interest in the context of its role in food intake regulation. While the gastric endocrine $\mathrm{X} / \mathrm{A}$-like cell was thought to be restricted to the stimulation of food intake due to the synthesis and release of the orexigenic peptide, ghrelin, new developments, namely the better characterization of desacyl ghrelin along with the identification of the anorexigenic hormone, nesfatin-1 in X/A-like cells provided a paradigm shift promoting 


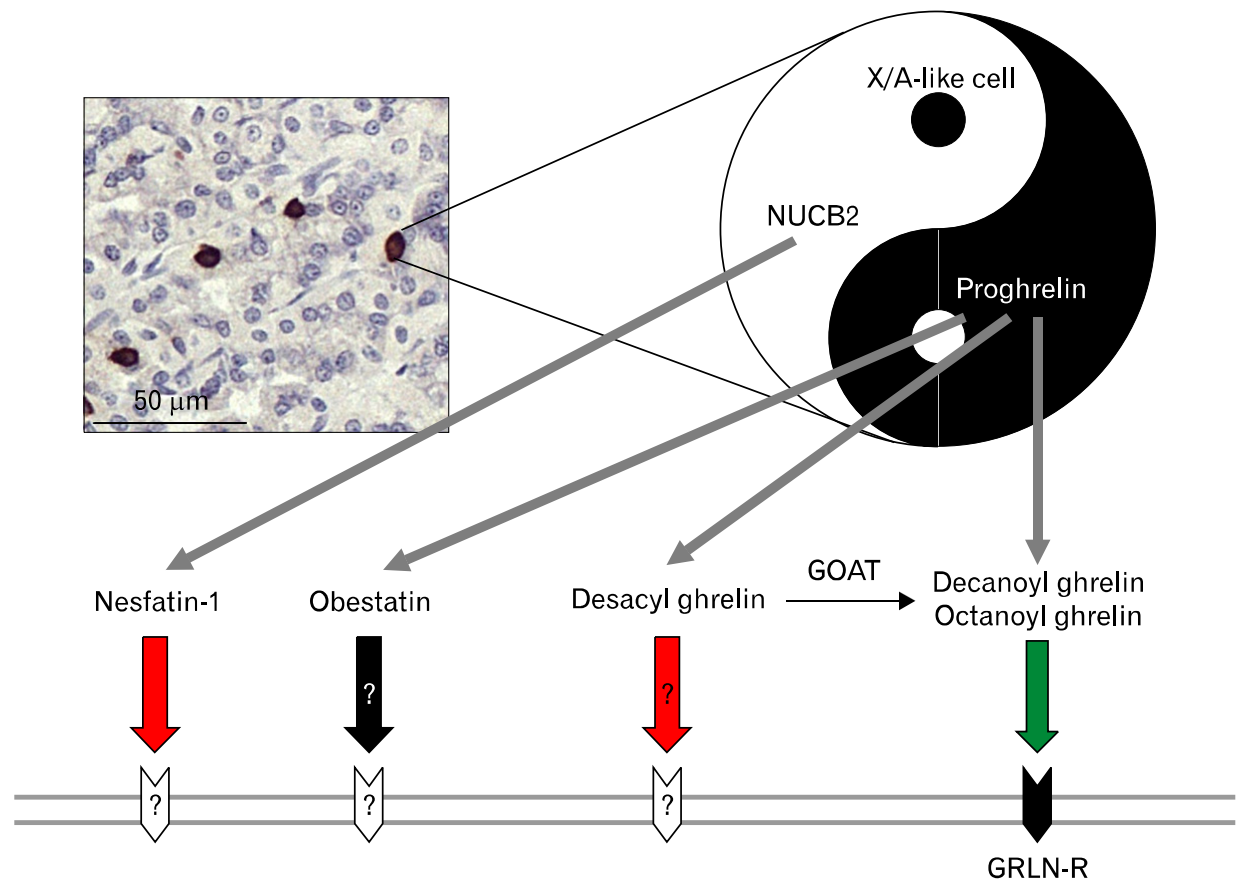

Figure. Peptide products of the gastric $\mathrm{X} / \mathrm{A}$-like cell and their effects on food intake. Red arrows indicate inhibition, the green arrow stimulation of food intake and the black a lack of effect on feeding. The question marks indicate lack of knowledge on effect and mediation. The insert shows rat gastric mucosa stained with an anti-ghrelin antibody. GOAT, ghrelin-O-acyltransferase; GRLN-R, ghrelin receptor; NUCB2, nucleobindin2. this cell type as a dual regulator of food intake (Figure). In addition to the effects on feeding, all these hormones are involved in long-term body homeostasis with a stimulatory role of ghrelin and an inhibitory effect described for desacyl ghrelin and nesfatin-1. Although our knowledge greatly increased over the past years, several important questions remain to be answered. Those encompass the identification of yet unknown receptors using desacyl ghrelin and nesfatin-1 as their endogenous selective ligands and related signaling pathways. In addition, mechanisms regulating the activity of the ghrelin acylating enzyme, GOAT remain to be characterized and the role of peripheral nesfatin-1 has to be better defined. New tools including the isolation of ghrelin cells using mouse models (eg, those expressing green fluorescent protein bound to the ghrelin promoter) will help to advance the field and answer those questions.

\section{References}

1. Rindi G, Leiter AB, Kopin AS, Bordi C, Solcia E. The "normal" endocrine cell of the gut: changing concepts and new evidences. Ann N Y Acad Sci 2004;1014:1-12.

2. Date Y, Kojima M, Hosoda H, et al. Ghrelin, a novel growth hormone-releasing acylated peptide, is synthesized in a distinct endocrine cell type in the gastrointestinal tracts of rats and humans. Endocrinology 2000;141:4255-4261.

3. Mizutani M, Atsuchi K, Asakawa A, et al. Localization of acyl ghrelin- and des-acyl ghrelin-immunoreactive cells in the rat stom- ach and their responses to intragastric $\mathrm{pH}$. Am J Physiol Gastrointest Liver Physiol 2009;297:G974-G980.

4. Sakata I, Nakamura K, Yamazaki M, et al. Ghrelin-producing cells exist as two types of cells, closed- and opened-type cells, in the rat gastrointestinal tract. Peptides 2002;23:531-536.

5. Kojima M, Hosoda H, Date Y, Nakazato M, Matsuo H, Kangawa $\mathrm{K}$. Ghrelin is a growth-hormone-releasing acylated peptide from stomach. Nature 1999;402:656-660.

6. Rindi G, Necchi V, Savio A, et al. Characterisation of gastric ghrelin cells in man and other mammals: studies in adult and fetal tissues. Histochem Cell Biol 2002;117:511-519.

7. Hiejima $\mathrm{H}$, Nishi $\mathrm{Y}$, Hosoda $\mathrm{H}$, et al. Regional distribution and the dynamics of n-decanoyl ghrelin, another acyl-form of ghrelin, upon fasting in rodents. Regul Pept 2009;156:47-56.

8. Zhang JV, Ren PG, Avsian-Kretchmer O, et al. Obestatin, a peptide encoded by the ghrelin gene, opposes ghrelin's effects on food intake. Science 2005;310:996-999.

9. Stengel A, Goebel M, Yakubov I, et al. Identification and characterization of nesfatin-1 immunoreactivity in endocrine cell types of the rat gastric oxyntic mucosa. Endocrinology 2009;150:232-238.

10. Kojima M, Kangawa K. The discovery of ghrelin: with a little luck and great passion. Preface. Peptides 2011;32:2153-2154.

11. Davenport AP, Bonner TI, Foord SM, et al. International Union of Pharmacology. LVI. Ghrelin receptor nomenclature, distribution, and function. Pharmacol Rev 2005;57:541-546.

12. Kojima M, Kangawa K. Ghrelin: structure and function. Physiol Rev 2005;85:495-522.

13. Nishi $\mathrm{Y}$, Hiejima $\mathrm{H}, \mathrm{Hosoda} \mathrm{H}$, et al. Ingested medium-chain fatty acids are directly utilized for the acyl modification of ghrelin. Endocrinology 2005;146:2255-2264.

14. Bednarek MA, Feighner SD, Pong SS, et al. Structure-function studies on the new growth hormone-releasing peptide, ghrelin: min- 
imal sequence of ghrelin necessary for activation of growth hormone secretagogue receptor 1a. J Med Chem 2000;43:4370-4376.

15. Yang J, Brown MS, Liang G, Grishin NV, Goldstein JL. Identification of the acyltransferase that octanoylates ghrelin, an appetite-stimulating peptide hormone. Cell 2008;132:387-396.

16. Gutierrez JA, Solenberg PJ, Perkins DR, et al. Ghrelin octanoylation mediated by an orphan lipid transferase. Proc Natl Acad Sci USA 2008;105:6320-6325.

17. Sakata I, Yang J, Lee CE, et al. Colocalization of ghrelin O-acyltransferase and ghrelin in gastric mucosal cells. Am J Physiol Endocrinol Metab 2009;297:E134-E141.

18. Stengel A, Goebel M, Wang L, Taché Y, Sachs G, Lambrecht NW. Differential distribution of ghrelin-O-acyltransferase (GOAT) immunoreactive cells in the mouse and rat gastric oxyntic mucosa. Biochem Biophys Res Commun 2010;392:67-71.

19. Hosoda H, Kojima M, Matsuo H, Kangawa K. Ghrelin and des-acyl ghrelin: two major forms of rat ghrelin peptide in gastrointestinal tissue. Biochem Biophys Res Commun 2000;279:909913.

20. Raff $\mathrm{H}$. Total and active ghrelin in developing rats during hypoxia. Endocrine 2003;21:159-161.

21. Stengel A, Keire D, Goebel M, et al. The RAPID method for blood processing yields new insight in plasma concentrations and molecular forms of circulating gut peptides. Endocrinology 2009;150: 5113-5118.

22. Soares JB, Leite-Moreira AF. Ghrelin, des-acyl ghrelin and obestatin: three pieces of the same puzzle. Peptides 2008;29:12551270.

23. Grönberg M, Tsolakis AV, Magnusson L, Janson ET, Saras J. Distribution of obestatin and ghrelin in human tissues: immunoreactive cells in the gastrointestinal tract, pancreas, and mammary glands. J Histochem Cytochem 2008;56:793-801.

24. Tsolakis AV, Grimelius L, Stridsberg M, et al. Obestatin/ghrelin cells in normal mucosa and endocrine tumours of the stomach. Eur J Endocrinol 2009;160:941-949.

25. Zhao CM, Furnes MW, Stenström B, Kulseng B, Chen D. Characterization of obestatin- and ghrelin-producing cells in the gastrointestinal tract and pancreas of rats: an immunohistochemical and electron-microscopic study. Cell Tissue Res 2008;331:575-587.

26. Oh-I S, Shimizu H, Satoh T, et al. Identification of nesfatin-1 as a satiety molecule in the hypothalamus. Nature 2006;443:709-712.

27. Brailoiu GC, Dun SL, Brailoiu E, et al. Nesfatin-1: distribution and interaction with a $G$ protein-coupled receptor in the rat brain. Endocrinology 2007;148:5088-5094.

28. Foo K, Brismar H, Broberger C. Distribution and neuropeptide coexistence of nucleobindin-2 mRNA/nesfatin-like immunoreactivity in the rat CNS. Neuroscience 2008;156:563-579.

29. Kohno D, Nakata M, Maejima Y, et al. Nesfatin-1 neurons in paraventricular and supraoptic nuclei of the rat hypothalamus coexpress oxytocin and vasopressin and are activated by refeeding. Endocrinology 2008;149:1295-1301.

30. Shimizu H, Oh-I S, Okada S, Mori M. Nesfatin-1: an overview and future clinical application. Endocr J 2009;56:537-543.

31. Ariyasu H, Takaya K, Tagami T, et al. Stomach is a major source of circulating ghrelin, and feeding state determines plasma ghrelin-like immunoreactivity levels in humans. J Clin Endocrinol Metab 2001;
$86: 4753-4758$

32. Jeon TY, Lee S, Kim HH, et al. Changes in plasma ghrelin concentration immediately after gastrectomy in patients with early gastric cancer. J Clin Endocrinol Metab 2004;89:5392-5396.

33. Date $\mathrm{Y}$, Nakazato M, Hashiguchi S, et al. Ghrelin is present in pancreatic alpha-cells of humans and rats and stimulates insulin secretion. Diabetes 2002;51:124-129.

34. Gnanapavan S, Kola B, Bustin SA, et al. The tissue distribution of the mRNA of ghrelin and subtypes of its receptor, GHS-R, in humans. J Clin Endocrinol Metab 2002;87:2988.

35. Barreiro ML, Gaytán F, Caminos JE, et al. Cellular location and hormonal regulation of ghrelin expression in rat testis. Biol Reprod 2002;67:1768-1776.

36. Cummings DE, Purnell JQ, Frayo RS, Schmidova K, Wisse BE, Weigle DS. A preprandial rise in plasma ghrelin levels suggests a role in meal initiation in humans. Diabetes 2001;50:1714-1719.

37. Tschöp M, Wawarta R, Riepl RL, et al. Post-prandial decrease of circulating human ghrelin levels. J Endocrinol Invest 2001;24: RC19-RC21.

38. Xu G, Li Y, An W, et al. Gastric mammalian target of rapamycin signaling regulates ghrelin production and food intake. Endocrinology 2009;150:3637-3644.

39. Toshinai K, Mondal MS, Nakazato M, et al. Upregulation of ghrelin expression in the stomach upon fasting, insulin-induced hypoglycemia, and leptin administration. Biochem Biophys Res Commun 2001;281:1220-1225.

40. Kim MS, Yoon CY, Park KH, et al. Changes in ghrelin and ghrelin receptor expression according to feeding status. Neuroreport 2003; 14:1317-1320

41. Tschöp M, Smiley DL, Heiman ML. Ghrelin induces adiposity in rodents. Nature 2000;407:908-913.

42. Cummings DE, Weigle DS, Frayo RS, et al. Plasma ghrelin levels after diet-induced weight loss or gastric bypass surgery. N Engl J Med 2002;346:1623-1630.

43. Tschöp M, Weyer C, Tataranni PA, Devanarayan V, Ravussin E, Heiman ML. Circulating ghrelin levels are decreased in human obesity. Diabetes 2001;50:707-709.

44. González CR, Vázquez MJ, López M, Diéguez C. Influence of chronic undernutrition and leptin on GOAT mRNA levels in rat stomach mucosa. J Mol Endocrinol 2008;41:415-421.

45. de la Cour CD, Norlén P, Håkanson R. Secretion of ghrelin from rat stomach ghrelin cells in response to local microinfusion of candidate messenger compounds: a microdialysis study. Regul Pept 2007;143:118-126.

46. Iwakura $\mathrm{H}$, Ariyasu $\mathrm{H}$, Hosoda $\mathrm{H}$, et al. Oxytocin and dopamine stimulate ghrelin secretion by the ghrelin-producing cell line, MGN3-1 in vitro. Endocrinology 2011;152:2619-2625.

47. Shimada M, Date Y, Mondal MS, et al. Somatostatin suppresses ghrelin secretion from the rat stomach. Biochem Biophys Res Commun 2003;302:520-525.

48. Stengel A, Goebel-Stengel M, Wang L, et al. Abdominal surgery inhibits circulating acyl ghrelin and ghrelin-O-acyltransferase levels in rats: role of the somatostatin receptor subtype 2. Am J Physiol Gastrointest Liver Physiol 2011;301:G239-G248.

49. Fischer T, Doll C, Jacobs S, Kolodziej A, Stumm R, Schulz S. Reassessment of sst2 somatostatin receptor expression in human 
normal and neoplastic tissues using the novel rabbit monoclonal antibody UMB-1. J Clin Endocrinol Metab 2008;93:4519-4524.

50. Madison LD, Scarlett JM, Levasseur P, et al. Prostacyclin signaling regulates circulating ghrelin during acute inflammation. J Endocrinol 2008;196:263-273.

51. Hagemann D, Holst JJ, Gethmann A, Banasch M, Schmidt WE, Meier JJ. Glucagon-like peptide 1 (GLP-1) suppresses ghrelin levels in humans via increased insulin secretion. Regul Pept 2007;143: 64-68.

52. Lippl F, Kircher F, Erdmann J, Allescher HD, Schusdziarra V. Effect of GIP, GLP-1, insulin and gastrin on ghrelin release in the isolated rat stomach. Regul Pept 2004;119:93-98.

53. Pérez-Tilve D, González-Matías L, Alvarez-Crespo M, et al. Exendin-4 potently decreases ghrelin levels in fasting rats. Diabetes 2007;56:143-151.

54. Brennan IM, Otto B, Feltrin KL, Meyer JH, Horowitz M, Feinle-Bisset C. Intravenous CCK-8, but not GLP-1, suppresses ghrelin and stimulates PYY release in healthy men. Peptides 2007;28:607-611.

55. Saad MF, Bernaba B, Hwu CM, et al. Insulin regulates plasma ghrelin concentration. J Clin Endocrinol Metab 2002;87:39974000 .

56. Ao Y, Go VL, Toy N, et al. Brainstem thyrotropin-releasing hormone regulates food intake through vagal-dependent cholinergic stimulation of ghrelin secretion. Endocrinology 2006;147:60046010.

57. Stengel A, Goebel M, Luckey A, Yuan PQ, Wang L, Taché Y. Cold ambient temperature reverses abdominal surgery-induced delayed gastric emptying and decreased plasma ghrelin levels in rats. Peptides 2010;31:2229-2235.

58. Mundinger TO, Cummings DE, Taborsky GJ Jr. Direct stimulation of ghrelin secretion by sympathetic nerves. Endocrinology 2006;147:2893-2901.

59. Zbucki RL, Sawicki B, Hryniewicz A, Winnicka MM. Cannabinoids enhance gastric X/A-like cells activity. Folia Histochem Cytobiol 2008;46:219-224.

60. Wang L, Murphy NP, Stengel A, Goebel-Stengel M, St Pierre D, Maidment NT, Taché Y. Ghrelin prevents levodopa-induced inhibition of gastric emptying and increases circulating levodopa in fasted rats. Neurogastroenterol Motil Published Online First: 23 March 2012. doi: 10.1111/j.1365-2982.2012.01904.x.

61. Thanthan S, Mekaru C, Seki N, et al. Endogenous ghrelin released in response to endothelin stimulates growth hormone secretion in cattle. Domest Anim Endocrinol 2010;38:1-12.

62. Kageyama H, Kitamura Y, Hosono T, et al. Visualization of ghrelin-producing neurons in the hypothalamic arcuate nucleus using ghrelin-EGFP transgenic mice. Regul Pept 2008;145:116-121.

63. Stengel A, Goebel M, Wang L, Reeve JR Jr, Taché Y, Lambrecht NW. Lipopolysaccharide differentially decreases plasma acyl and desacyl ghrelin levels in rats: potential role of the circulating ghrelin-acylating enzyme GOAT. Peptides 2010;31:1689-1696.

64. Hattori N, Saito T, Yagyu T, Jiang BH, Kitagawa K, Inagaki C. $\mathrm{GH}, \mathrm{GH}$ receptor, $\mathrm{GH}$ secretagogue receptor, and ghrelin expression in human T cells, B cells, and neutrophils. J Clin Endocrinol Metab 2001;86:4284-4291.

65. Schellekens H, Dinan TG, Cryan JF. Lean mean fat reducing "ghrelin" machine: hypothalamic ghrelin and ghrelin receptors as therapeutic targets in obesity. Neuropharmacology 2010;58:2-16.

66. Xu L, Depoortere I, Tomasetto C, et al. Evidence for the presence of motilin, ghrelin, and the motilin and ghrelin receptor in neurons of the myenteric plexus. Regul Pept 2005;124:119-125.

67. Holst B, Cygankiewicz A, Jensen TH, Ankersen M, Schwartz TW. High constitutive signaling of the ghrelin receptor - identification of a potent inverse agonist. Mol Endocrinol 2003;17:22012210.

68. Els S, Beck-Sickinger AG, Chollet C. Ghrelin receptor: high constitutive activity and methods for developing inverse agonists. Methods Enzymol 2010;485:103-121.

69. Jiang H, Betancourt L, Smith RG. Ghrelin amplifies dopamine signaling by cross talk involving formation of growth hormone secretagogue receptor/dopamine receptor subtype 1 heterodimers. Mol Endocrinol 2006;20:1772-1785.

70. Camiña JP, Carreira MC, El Messari S, Llorens-Cortes C, Smith RG, Casanueva FF. Desensitization and endocytosis mechanisms of ghrelin-activated growth hormone secretagogue receptor 1a. Endocrinology 2004;145:930-940.

71. Cassoni $\mathrm{P}$, Papotti $\mathrm{M}$, Ghè $\mathrm{C}$, et al. Identification, characterization, and biological activity of specific receptors for natural (ghrelin) and synthetic growth hormone secretagogues and analogs in human breast carcinomas and cell lines. J Clin Endocrinol Metab 2001;86: 1738-1745.

72. Cassoni $\mathrm{P}$, Ghè C, Marrocco T, et al. Expression of ghrelin and biological activity of specific receptors for ghrelin and des-acyl ghrelin in human prostate neoplasms and related cell lines. Eur J Endocrinol 2004;150:173-184.

73. Gauna C, Delhanty PJ, van Aken MO, et al. Unacylated ghrelin is active on the INS-1E rat insulinoma cell line independently of the growth hormone secretagogue receptor type $1 \mathrm{a}$ and the corticotropin releasing factor 2 receptor. Mol Cell Endocrinol 2006;251:103111.

74. Gourcerol G, Taché Y. Obestatin - a ghrelin-associated peptide that does not hold its promise to suppress food intake and motility. Neurogastroenterol Motil 2007;19:161-165.

75. Zizzari P, Longchamps R, Epelbaum J, Bluet-Pajot MT. Obestatin partially affects ghrelin stimulation of food intake and growth hormone secretion in rodents. Endocrinology 2007;148:1648-1653.

76. Lauwers E, Landuyt B, Arckens L, Schoofs L, Luyten W. Obestatin does not activate orphan $G$ protein-coupled receptor GPR39. Biochem Biophys Res Commun 2006;351:21-25.

77. Tremblay F, Perreault M, Klaman LD, Tobin JF, Smith E, Gimeno RE. Normal food intake and body weight in mice lacking the G protein-coupled receptor GPR39. Endocrinology 2007;148: 501-506.

78. Holst B, Egerod KL, Schild E, et al. GPR39 signaling is stimulated by zinc ions but not by obestatin. Endocrinology 2007;148:13-20.

79. Chartrel N, Alvear-Perez R, Leprince J, et al. Comment on "Obestatin, a peptide encoded by the ghrelin gene, opposes ghrelin's effects on food intake". Science 2007;315:766; author reply 766.

80. Zhang JV, Klein C, Ren P-G, et al. Response to Comment on "Obestatin, a Peptide Encoded by the Ghrelin Gene, Opposes Ghrelin's Effects on Food Intake”. Science 2007;315:766d.

81. Zhang JV, Jahr H, Luo CW, et al. Obestatin induction of early-re- 
sponse gene expression in gastrointestinal and adipose tissues and the mediatory role of $\mathrm{G}$ protein-coupled receptor, GPR39. Mol Endocrinol 2008;22:1464-1475.

82. Holst B, Holliday ND, Bach A, Elling CE, Cox HM, Schwartz TW. Common structural basis for constitutive activity of the ghrelin receptor family. J Biol Chem 2004;279:53806-53817.

83. Tsuchiya T, Shimizu H, Yamada M, et al. Fasting concentrations of nesfatin-1 are negatively correlated with body mass index in non-obese males. Clin Endocrinol (Oxf) 2010;73:484-490.

84. Li QC, Wang HY, Chen X, Guan HZ, Jiang ZY. Fasting plasma levels of nesfatin- 1 in patients with type 1 and type 2 diabetes mellitus and the nutrient-related fluctuation of nesfatin-1 level in normal humans. Regul Pept 2010;159:72-77.

85. Ogiso K, Asakawa A, Amitani H, et al. Plasma nesfatin-1 concentrations in restricting-type anorexia nervosa. Peptides 2011;32:150153.

86. Ramanjaneya M, Chen J, Brown JE, et al. Identification of nesfatin-1 in human and murine adipose tissue: a novel depot-specific adipokine with increased levels in obesity. Endocrinology 2010;151: 3169-3180.

87. Tan BK, Hallschmid M, Kern W, Lehnert H, Randeva HS. Decreased cerebrospinal fluid/plasma ratio of the novel satiety molecule, nesfatin-1/NUCB-2, in obese humans: evidence of nesfatin-1/NUCB-2 resistance and implications for obesity treatment. J Clin Endocrinol Metab 2011;96:E669-E673.

88. Gonzalez R, Kerbel B, Chun A, Unniappan S. Molecular, cellular and physiological evidences for the anorexigenic actions of nesfatin-1 in goldfish. PLoS One 2010;5:e15201.

89. García-Galiano D, Navarro VM, Roa J, et al. The anorexigenic neuropeptide, nesfatin-1, is indispensable for normal puberty onset in the female rat. J Neurosci 2010;30:7783-7792.

90. Goebel M, Stengel A, Taché Y. Continued controversy on obestatin as a gut hormone influencing food intake and gastrointestinal motility. Obes Metab 2008;4:143-148.

91. Chen CY, Asakawa A, Fujimiya M, Lee SD, Inui A. Ghrelin gene products and the regulation of food intake and gut motility. Pharmacol Rev 2009;61:430-481.

92. García-Galiano D, Navarro VM, Gaytan F, Tena-Sempere M. Expanding roles of NUCB2/nesfatin-1 in neuroendocrine regulation. J Mol Endocrinol 2010;45:281-290.

93. Suzuki K, Jayasena CN, Bloom SR. The gut hormones in appetite regulation. J Obes 2011;2011:528401.

94. Wren AM, Small CJ, Ward HL, et al. The novel hypothalamic peptide ghrelin stimulates food intake and growth hormone secretion. Endocrinology 2000;141:4325-4328.

95. Tang-Christensen M, Vrang N, Ortmann S, Bidlingmaier M, Horvath TL, Tschöp M. Central administration of ghrelin and agouti-related protein (83-132) increases food intake and decreases spontaneous locomotor activity in rats. Endocrinology 2004;145: 4645-4652.

96. Druce MR, Wren AM, Park AJ, et al. Ghrelin increases food intake in obese as well as lean subjects. Int J Obes (Lond) 2005;29: 1130-1136.

97. Salome N, Haage D, Perrissoud D, et al. Anorexigenic and electrophysiological actions of novel ghrelin receptor (GHS-R1A) antagonists in rats. Eur J Pharmacol 2009;612:167-173.
98. Sun Y, Wang P, Zheng H, Smith RG. Ghrelin stimulation of growth hormone release and appetite is mediated through the growth hormone secretagogue receptor. Proc Natl Acad Sci USA 2004;101:4679-4684.

99. Zigman JM, Nakano Y, Coppari R, et al. Mice lacking ghrelin receptors resist the development of diet-induced obesity. J Clin Invest 2005;115:3564-3572.

100. Banks WA, Tschöp M, Robinson SM, Heiman ML. Extent and direction of ghrelin transport across the blood-brain barrier is determined by its unique primary structure. J Pharmacol Exp Ther 2002;302:822-827.

101. Pan W, Tu H, Kastin AJ. Differential BBB interactions of three ingestive peptides: obestatin, ghrelin, and adiponectin. Peptides 2006; 27:911-916.

102. Date Y, Murakami N, Toshinai K, et al. The role of the gastric afferent vagal nerve in ghrelin-induced feeding and growth hormone secretion in rats. Gastroenterology 2002;123:1120-1128.

103. Sakata I, Yamazaki M, Inoue K, Hayashi Y, Kangawa K, Sakai T. Growth hormone secretagogue receptor expression in the cells of the stomach-projected afferent nerve in the rat nodose ganglion. Neurosci Lett 2003;342:183-186.

104. Arnold M, Mura A, Langhans W, Geary N. Gut vagal afferents are not necessary for the eating-stimulatory effect of intraperitoneally injected ghrelin in the rat. J Neurosci 2006;26:11052-11060.

105. Davies JS, Kotokorpi P, Eccles SR, et al. Ghrelin induces abdominal obesity via GHS-R-dependent lipid retention. Mol Endocrinol 2009;23:914-924.

106. Strassburg S, Anker S, Castaneda T, et al. Long-term effects of ghrelin and ghrelin receptor agonists on energy balance in rats. Am J Physiol Endocrinol Metab 2008;295:E78-E84.

107. Pfluger PT, Kirchner H, Günnel S, et al. Simultaneous deletion of ghrelin and its receptor increases motor activity and energy expenditure. Am J Physiol Gastrointest Liver Physiol 2008;294:G610G618.

108. Sun Y, Ahmed S, Smith RG. Deletion of ghrelin impairs neither growth nor appetite. Mol Cell Biol 2003;23:7973-7981.

109. Theander-Carrillo C, Wiedmer P, Cettour-Rose P, et al. Ghrelin action in the brain controls adipocyte metabolism. J Clin Invest 2006;116:1983-1993.

110. Kirchner H, Gutierrez JA, Solenberg PJ, et al. GOAT links dietary lipids with the endocrine control of energy balance. Nat Med 2009; 15:741-745.

111. Lu S, Guan JL, Wang QP, et al. Immunocytochemical observation of ghrelin-containing neurons in the rat arcuate nucleus. Neurosci Lett 2002;321:157-160.

112. Cowley MA, Smith RG, Diano S, et al. The distribution and mechanism of action of ghrelin in the CNS demonstrates a novel hypothalamic circuit regulating energy homeostasis. Neuron 2003;37: 649-661.

113. Schwartz MW, Woods SC, Porte D Jr, Seeley RJ, Baskin DG. Central nervous system control of food intake. Nature 2000;404: 661-671.

114. Abizaid A, Horvath TL. Brain circuits regulating energy homeostasis. Regul Pept 2008;149:3-10.

115. Guan JL, Wang QP, Kageyama H, Takenoya F, et al. Synaptic interactions between ghrelin- and neuropeptide $\mathrm{Y}$-containing neurons 
in the rat arcuate nucleus. Peptides 2003;24:1921-1928.

116. Wang L, Saint-Pierre DH, Taché Y. Peripheral ghrelin selectively increases Fos expression in neuropeptide $\mathrm{Y}$ - synthesizing neurons in mouse hypothalamic arcuate nucleus. Neurosci Lett 2002;325: 47-51.

117. Kamegai J, Tamura H, Shimizu T, Ishii S, Sugihara H, Wakabayashi I. Chronic central infusion of ghrelin increases hypothalamic neuropeptide $\mathrm{Y}$ and Agouti-related protein mRNA levels and body weight in rats. Diabetes 2001;50:2438-2443.

118. Nakazato M, Murakami N, Date $\mathrm{Y}$, et al. A role for ghrelin in the central regulation of feeding. Nature 2001;409:194-198.

119. Chen HY, Trumbauer ME, Chen AS, et al. Orexigenic action of peripheral ghrelin is mediated by neuropeptide $\mathrm{Y}$ and agouti-related protein. Endocrinology 2004;145:2607-2612.

120. Andrews ZB, Liu ZW, Walllingford N, et al. UCP2 mediates ghrelin's action on NPY/AgRP neurons by lowering free radicals. Nature 2008;454:846-851.

121. López M, Lage R, Saha AK, et al. Hypothalamic fatty acid metabolism mediates the orexigenic action of ghrelin. Cell Metab 2008;7: 389-399.

122. Andrews ZB, Erion DM, Beiler R, Choi CS, Shulman GI, Horvath TL. Uncoupling protein-2 decreases the lipogenic actions of ghrelin. Endocrinology 2010;151:2078-2086.

123. Inhoff $\mathrm{T}$, Wiedenmann $\mathrm{B}, \mathrm{Klapp} \mathrm{BF}, \mathrm{Mönnikes} \mathrm{H,} \mathrm{Kobelt} \mathrm{P}$. Is desacyl ghrelin a modulator of food intake? Peptides 2009;30:991994.

124. Chen CY, Inui A, Asakawa A, et al. Des-acyl ghrelin acts by CRF type 2 receptors to disrupt fasted stomach motility in conscious rats. Gastroenterology 2005;129:8-25.

125. Asakawa A, Inui A, Fujimiya M, et al. Stomach regulates energy balance via acylated ghrelin and desacyl ghrelin. Gut 2005;54:1824.

126. Inhoff T, Mönnikes H, Noetzel S, et al. Desacyl ghrelin inhibits the orexigenic effect of peripherally injected ghrelin in rats. Peptides 2008;29:2159-2168.

127. Neary NM, Druce MR, Small CJ, Bloom SR. Acylated ghrelin stimulates food intake in the fed and fasted states but desacylated ghrelin has no effect. Gut 2006;55:135.

128. Toshinai K, Yamaguchi H, Sun Y, et al. Des-acyl ghrelin induces food intake by a mechanism independent of the growth hormone secretagogue receptor. Endocrinology 2006;147:2306-2314.

129. Iwakura $\mathrm{H}$, Ariyasu $\mathrm{H}, \mathrm{Li} \mathrm{Y}$, et al. A mouse model of ghrelinoma exhibited activated growth hormone-insulin-like growth factor I axis and glucose intolerance. Am J Physiol Endocrinol Metab 2009;297: E802-E811.

130. Ariyasu H, Takaya K, Iwakura H, et al. Transgenic mice overexpressing des-acyl ghrelin show small phenotype. Endocrinology 2005;146:355-364.

131. Zhang W, Chai B, Li JY, Wang H, Mulholland MW. Effect of des-acyl ghrelin on adiposity and glucose metabolism. Endocrinology 2008;149:4710-4716.

132. Rodriguez A, Gómez-Ambrosi J, Catalán V, et al. Acylated and desacyl ghrelin stimulate lipid accumulation in human visceral adipocytes. Int J Obes (Lond) 2009;33:541-552.

133. Bresciani E, Rapetti $\mathrm{D}$, Donà $\mathrm{F}$, et al. Obestatin inhibits feeding but does not modulate $\mathrm{GH}$ and corticosterone secretion in the rat. $\mathrm{J}$
Endocrinol Invest 2006;29:RC16-RC18.

134. Carlini VP, Schiöth HB, Debarioglio SR. Obestatin improves memory performance and causes anxiolytic effects in rats. Biochem Biophys Res Commun 2007;352:907-912.

135. Nagaraj S, Peddha MS, Manjappara UV. Fragments of obestatin as modulators of feed intake, circulating lipids, and stored fat. Biochem Biophys Res Commun 2008;366:731-737.

136. Lagaud GJ, Young A, Acena A, Morton MF, Barrett TD, Shankley NP. Obestatin reduces food intake and suppresses body weight gain in rodents. Biochem Biophys Res Commun 2007;357: 264-269.

137. Seoane LM, Al-Massadi O, Pazos Y, Pagotto U, Casanueva FF. Central obestatin administration does not modify either spontaneous or ghrelin-induced food intake in rats. J Endocrinol Invest 2006; 29:RC13-RC15.

138. Moechars D, Depoortere I, Moreaux B, et al. Altered gastrointestinal and metabolic function in the GPR39-obestatin receptor-knockout mouse. Gastroenterology 2006;131:1131-1141.

139. Gourcerol G, Million M, Adelson DW, et al. Lack of interaction between peripheral injection of CCK and obestatin in the regulation of gastric satiety signaling in rodents. Peptides 2006;27:2811-2819.

140. Samson WK, White MM, Price C, Ferguson AV. Obestatin acts in brain to inhibit thirst. Am J Physiol Regul Integr Comp Physiol 2007;292:R637-R643.

141. Yamamoto D, Ikeshita N, Daito R, et al. Neither intravenous nor intracerebroventricular administration of obestatin affects the secretion of GH, PRL, TSH and ACTH in rats. Regul Pept 2007;138: 141-144.

142. Nogueiras R, Pfluger $P$, Tovar $\mathrm{S}$, et al. Effects of obestatin on energy balance and growth hormone secretion in rodents. Endocrinology 2007;148:21-26.

143. Mondal M, Toshinai K, Ueno H, Koshinaka K, Nakazato M. Characterization of obestatin in rat and human stomach and plasma, and its lack of acute effect on feeding behavior in rodents. J Endocrinol 2008;198:339-346.

144. Kobelt P, Wisser AS, Stengel A, et al. Peripheral obestatin has no effect on feeding behavior and brain Fos expression in rodents. Peptides 2008;29:1018-1027.

145. Depoortere I, Thijs T, Moechars D, De Smet B, Ver Donck L, Peeters TL. Effect of peripheral obestatin on food intake and gastric emptying in ghrelin-knockout mice. Br J Pharmacol 2008;153: 1550-1557.

146. Annemie VD, Debby VD, Valentijn V, et al. Central administration of obestatin fails to show inhibitory effects on food and water intake in mice. Regul Pept 2009;156:77-82.

147. Brunetti L, Leone S, Orlando G, et al. Effects of obestatin on feeding and body weight after standard or cafeteria diet in the rat. Peptides 2009;30:1323-1327.

148. Unniappan S, Speck M, Kieffer TJ. Metabolic effects of chronic obestatin infusion in rats. Peptides 2008;29:1354-1361.

149. Gourcerol G, St-Pierre DH, Taché Y. Lack of obestatin effects on food intake: should obestatin be renamed ghrelin-associated peptide (GAP)? Regul Pept 2007;141:1-7.

150. Maejima Y, Sedbazar U, Suyama S, et al. Nesfatin-1-regulated oxytocinergic signaling in the paraventricular nucleus causes anorexia through a leptin-independent melanocortin pathway. Cell Metab 
2009;10:355-365.

151. Stengel A, Goebel M, Taché Y. Nesfatin-1: a novel inhibitory regulator of food intake and body weight. Obes Rev 2011;12:261-271.

152. Goebel M, Stengel A, Wang L, Taché Y. Central nesfatin-1 reduces the nocturnal food intake in mice by reducing meal size and increasing inter-meal intervals. Peptides 2011;32:36-43.

153. Stengel A, Goebel M, Wang L, et al. Central nesfatin-1 reduces dark-phase food intake and gastric emptying in rats: differential role of corticotropin-releasing factor2 receptor. Endocrinology 2009; 150:4911-4919

154. Yosten GL, Samson WK. The anorexigenic and hypertensive effects of nesfatin- 1 are reversed by pretreatment with an oxytocin receptor antagonist. Am J Physiol Regul Integr Comp Physiol 2010; 298:R1642-R1647.

155. Atsuchi K, Asakawa A, Ushikai M, et al. Centrally administered nesfatin-1 inhibits feeding behaviour and gastroduodenal motility in mice. Neuroreport 2010;21:1008-1011.

156. Zorrilla EP, Taché $Y$, Koob GF. Nibbling at CRF receptor control of feeding and gastrocolonic motility. Trends Pharmacol Sci 2003; 24:421-427.

157. Tabarin A, Diz-Chaves Y, Consoli D, et al. Role of the corticotropin-releasing factor receptor type 2 in the control of food intake in mice: a meal pattern analysis. Eur J Neurosci 2007;26:2303-2314.

158. Yosten GL, Samson WK. Nesfatin-1 exerts cardiovascular actions in brain: possible interaction with the central melanocortin system.
Am J Physiol Regul Integr Comp Physiol 2009;297:R330-R336.

159. Nonogaki K, Ohba Y, Sumii M, Oka Y. Serotonin systems upregulate the expression of hypothalamic NUCB2 via $5-\mathrm{HT}_{2 \mathrm{C}}$ receptors and induce anorexia via a leptin-independent pathway in mice. Biochem Biophys Res Commun 2008;372:186-190.

160. Price CJ, Samson WK, Ferguson AV. Nesfatin-1 inhibits NPY neurons in the arcuate nucleus. Brain Res 2008;1230:99-106.

161. Xu B, Kalra PS, Farmerie WG, Kalra SP. Daily changes in hypothalamic gene expression of neuropeptide $\mathrm{Y}$, galanin, proopiomelanocortin, and adipocyte leptin gene expression and secretion: effects of food restriction. Endocrinology 1999;140:2868-2875.

162. Taheri S, Sunter D, Dakin C, et al. Diurnal variation in orexin A immunoreactivity and prepro-orexin mRNA in the rat central nervous system. Neurosci Lett 2000;279:109-112.

163. Lu XY, Shieh KR, Kabbaj M, Barsh GS, Akil H, Watson SJ. Diurnal rhythm of agouti-related protein and its relation to corticosterone and food intake. Endocrinology 2002;143:3905-3915.

164. Shimizu H, Oh-I S, Hashimoto K, et al. Peripheral administration of nesfatin-1 reduces food intake in mice: the leptin-independent mechanism. Endocrinology 2009;150:662-671.

165. Iwasaki Y, Nakabayashi H, Kakei M, Shimizu H, Mori M, Yada T. Nesfatin-1 evokes $\mathrm{Ca}^{2+}$ signaling in isolated vagal afferent neurons via $\mathrm{Ca}^{2+}$ influx through $\mathrm{N}$-type channels. Biochem Biophys Res Commun 2009;390:958-962. 